\title{
NEWBUILD GENTRIFICATION, TELE-URBANIZATION AND URBAN GROWTH: PLACING THE CITIES OF THE POST-COMMUNIST SOUTH IN THE GENTRIFICATION DEBATE
}

\begin{abstract}
GENTILE, M., SALUKVADZE, J., GOGISHVILI, D. (2015): Newbuild gentrification, tele-urbanization and urban growth: placing the cities of the post-Communist South in the gentrification debate. Geografie, 120, No. 2, pp. 134-163. - This paper explores new-build developments in Tbilisi, Georgia. Based on interviews with developers and with residents and neighbours of new-build developments, we examine the burgeoning of new-build housing projects in a lower middle income post-Communist country. By doing so, we respond to Lees' (2012) recent call for the exploration of new horizons in gentrification research, which would allow us to transcend the boundaries established by Global-North theorizations - such as those surrounding "new-build gentrification". While theoretically tantalizing, interpreting the observed developments through this lens, which a superficial observation of the phenomenon might encourage, is not fruitful. Instead, the case of Tbilisi illustrates the need for an appropriate assessment of context: rather than representing a revanchist return to the city of the middle classes, new-builds in Tbilisi appear, largely, to accommodate demographic growth and "deposited" diaspora capital. This, in turn, leads to intense rates of construction despite high vacancy rates - a process which could be viewed as a form of remote-controlled urban growth, or tele-urbanization.

KEY WORDS: Georgia - Tbilisi - new-build gentrification - tele-urbanization - urbanization - housing - post-Communist city.
\end{abstract}

\section{Introduction}

In a recent contribution, Loretta Lees (2012) calls for greater dialogue between research on gentrification and the study of comparative urbanism. In particular, she notes that the "visceral emergence of state-led gentrification in the Global South" (p. 156) necessitates the attention of (critical) urban geographers, warning that gentrification in the South should not be viewed or interpreted as a recreation of the patterns in the "supposed centre". State-led gentrification in the Global South is typically characterized by vast newbuild projects, often preceded by kindred demolition or slum clearance programmes which dramatically rearrange the morphological and social spatial structures of cities in ways that supposedly run against the interests of the population that finds itself displaced (Choi 2014). This pattern resonates within the burgeoning literature on newbuild gentrification (e.g., Davidson, Lees 2005; 2010; Davidson 2007; Stabrowski 2014) which, alas, has developed conceptions and interpretations of gentrification and urban social change that are deeply rooted in the experience of a restricted number of neighbourhoods within an 
even more limited number of globally significant cities. Perhaps this does not matter, for if one is to accept N. Smith's (2002) frequently cited suggestion that gentrification has become a global urban strategy that accords a pivotal role to the state and to global capital, then it is reasonable to expect that its fundamentally similar origin will produce gentrified spaces in which commonalities overshadow the fact that the underlying processes "spring from quite assorted local economies and cultural ensembles and connect in many complicated ways to wider national and global political economies" (p. 439). In other words, the spread of gentrification is unidirectional: from the Global North's major cities down to the lower levels of the urban hierarchy, from the Global North to the Global South. Context matters, but not so much: be it in Lancaster, PA, or in Český Krumlov - towns mentioned by Smith (2002) as having experienced gentrification - it is still much the same thing.

Of course, there are others who see greater value in a detailed appreciation of context (e.g., Bernt 2012), and the comparative urbanism perspective advocated by Robinson $(2002,2006,2011)$ and encouraged by Lees (2012) opens new avenues for the theorization of gentrification. In a prompt response to Lees' call, Lemanski's (2014) recently launched concept of hybrid gentrification offers an example of how a careful analysis of neighbourhood change in Cape Town townships may contribute to the development of theories originating from the Global South, which may in turn prove helpful to (re-?)interpret gentrification elsewhere. In Lemanski's case, the buyers of the "gentrified" properties are wealthy, but the settlers are only slightly better-off than the preceding (displaced in critical parlance) occupants, and certainly not members of the gentry. Rather than gentrification, or downward raiding as similar forms of "slight" gentrification are referred to in the development literature, the result of this elusive process is that the townships are increasingly settled by lowwage earners employed in the formal sector, while the previous occupants (who had earlier benefited from a one-time housing subsidy) tend to return to the informal settlements from which they originated.

While post-Communist cities tend to be overlooked by even the most globally attentive scholars (Robinson 2011, Lees 2012), a recent article in this journal suggests that these cities could carry a similar theory "export" potential (Sjöberg 2014). Accordingly, this paper's goal is to respond to this challenge by exploring the development of new housing construction in Tbilisi, Georgia, through the lens of the newbuild gentrification debate. Tbilisi may be regarded as an example of a metropolis that is both "post-Communist" and belonging to the Global South. It is, in other words, a city of the Post-Communist South. In a nutshell, our research questions are who builds, who buys and what happens to the neighbourhood? We address these questions by discussing the findings from interviews with developers and real estate professionals, newbuild residents/ buyers, and "non-gentrifying" locals in Tbilisi, Georgia, and our intent is largely explorative.

There has been an increased awareness among students of the post-Communist city of the necessity to extend the scope of research and theorization beyond the horizon of the region's largest and most centrally located metropolitan areas (Borén, Gentile 2007; Marcińczak, Sagan 2011; Grubbauer 2012; Sýkora, Bouzarovski 2012; Sjöberg 2014). The transformations that have taken place in 
the cities of the post-Communist South are a particularly sore spot, although recent work by teams of (mostly) anthropologists and ethnographers (Alexander, Buchli, Humphrey 2007; Darieva, Kaschuba, Krebs 2011) provide a wide range of insights into the specific cultural expressions of post-Soviet urbanism in the Caucasian and Central Asian Republics. ${ }^{1}$ Within the geographical sciences, the attempts to propel the post-Communist South into urban theory have thus far been limited, despite the growing number of fruitful, if isolated, case studies on individual cities (see Sjöberg 2014 for an overview).

A rare piece of comparative work that touches upon gentrification is van Kempen and Murie's (2009) contribution on residential segregation in European cities, which argued that urban renewal processes and especially gentrification and brownfield redevelopment in Western and Eastern Europe are fundamentally similar in their spatial outcome but not in their underlying economic logic. In Central and Eastern Europe, the rationale for urban renewal is profit seeking by exploiting the inner city rent gaps caused by decades of disinvestment in its housing stock (see also Sýkora 1993; Nagy, Timár 2012); in Western Europe, it tends to be part of an overarching political and social agenda aimed at creating the conditions for social mix and regeneration, a policy that critics have referred to as prefabricated (Wacquant 2008), "sugarcoating" gentrification (Smith 2002). Also, some recent work on residential segregation patterns (Marcińczak, Gentile, Stępniak 2013; Marcińczak et al. 2014 and especially Marcińczak et al. 2015) has attempted to breach the gap between "Eastern" empirical studies and "Western" theory by interpreting the observed patterns in the light of the experience of and theorizations on cities in established Capitalist nations. This important step represents a theoretical empowerment of post-Communist cities, but it still falls short of being able to offer a novel theoretical imagination. In Sjöberg's (2014) words, it is a case of "imports" rather than of "exports".

\section{Disputes on (newbuild) gentrification}

Over the past few decades, the meaning of the concept of gentrification has proved to be rather elastic and controversial, and although Slater (2006) suggests that squabbles over definition obfuscate the consequences of gentrification, the way gentrification is defined appears to influence policy (Bernt, Holm 2009). While initially geographically limited to the social changes taking place in the existing housing stock of the inner city (of London at first, see Glass 1964), the concept of gentrification has now swelled beyond recognition, expanding into both newbuild developments erected on urban non-residential sites (Davidson, Lees 2005) and rural areas in the guise of "rural gentrification" (Phillips 1993, 2004). Seen through the critical geography perspective, the widening scope of the concept inevitably reflects the fact that gentrification has become a critical

1 The Caucasus includes Armenia, Azerbaijan and Georgia, as well as the regions of the North Caucasus belonging to the Russian Federation (e.g., Dagestan, Chechnya, North Ossetia). The post-Communist Central Asian Republics are Kazakhstan, Kyrgyzstan, Uzbekistan, Turkmenistan and Tajikistan. 
constituent in the remaking of the Capitalist city - it has become a global urban strategy (Smith 2002) in which the state has taken an active role in what is known as the "third wave" of gentrification (Hackworth, Smith 2001). During this stage, gentrification is no longer understood as a local anomaly in a limited number of global cities, but rather as a generalized class remaking present across the world and at all levels of the urban hierarchy, a process in which there are clear winners (the gentrifiers among the middle and higher classes) and losers (the displaced members of the working class) and which involves the unprecedented exploitation of rent gaps (Smith 1979) accumulated during decades of disinvestment. Following this line of argument, the spatial logic of capital accumulation, rather than the individual preferences of people, lies at the core of gentrification. Newbuild developments are but the latest expression of this, and the fact that they represent a form of rapid colonization rather than a creeping frontier (Davidson 2007, p. 503) entails that they may have dramatic consequences for the evolution of the social geography of cities across the world. Others, however, see less value in the inflation of the concept, suggesting that it has expanded beyond the point of being useful (Boddy 2007, p. 98, Hamnett 2009, for an overview of the debate on the status of newbuilds vis-à-vis gentrification, see Doucet et al. 2011). If newbuild developments are a form of gentrification, then, considering that all new units are ceteris paribus significantly more expensive than the older dwellings in their immediate proximity, all new free market housing construction anywhere within any city anywhere in the world will always be a form of gentrification. ${ }^{2}$ If this is the case, then the global scope and colonizing character becomes an undisputable truth, but does this make the concept more helpful? In addition, the narrative of unstoppable globalized gentrification crowds out a number of empirically well-founded alternative conceptualizations and explanations, most notably reurbanization and residentialization (Buzar, Hall, Ogden 2007; Kabisch, Haase, Haase 2010) - concepts that Wacquant (2008) dismissed as mere euphemisms for gentrification rather than considering them as competing theoretical setups. Finally, it is unable to explain why gentrification in non-global cities (still?) appears to be associated with the early adulthood lifecycle stage (Bridge 2006, Doucet 2009). In this light, gentrification is but one expression of reurbanization (Buzar, Hall, Ogden 2007), one that involves "transitory urbanites" (Haase, Grossmann, Steinführer 2012) whose future lies elsewhere in the city.

Like gentrification as a whole, the topic of newbuild "gentrification" is an arena of heated academic dispute played out between proponents of the "critical" school, which is heavily influenced by Marxism, and those who would rather adhere to the "less-than-critical" approach, which includes a wide variety of takes that have in common the fact that they question the grand rent-gapsexplain-all narrative that is central to the critical approach (Hamnett, 1991, Freeman 2009, Rérat, Söderström, Piguet 2010).

When it comes to newbuild gentrification the key aspect relates to whether or not newbuild developments cause displacement, direct or indirect. And again,

2 Only sprawling suburban estates would manage to escape the label, as long they do not interfere with the social structure of the surrounding rural areas (causing rural gentrification). 
at the core of the dispute lies the matter of definition, operationalization and measurement, seasoned with a sprinkle of ideology, a hint of epistemological controversy, and a dash of geographically-bounded parochialism. Some of the arguments for and against the displacement thesis are versions of ideas that have already been expressed in relation to "traditional" gentrification, and it is occasionally difficult to keep them apart, not least because newbuild and traditional gentrification may coexist side by side.

At the most basic level, because newbuilds are usually erected on vacant or previously non-residential plots, they do not cause displacement and are therefore not a problem (Boddy 2007). This explains Freeman's (2008) observation that gentrification receives a mixed response by local residents, and the "striking lack of major critical remarks" found by Doucet (2009, p. 312). Critical scholars see things differently: recognizing that newbuilds rarely displace people directly, they tend to emphasize indirect displacement, which may be expressed in various forms of economic, social and cultural pressure, including different combinations thereof (Slater 2009).

However, contrary to conventional wisdom among critical geographers, gentrification has even been shown to help retain local residents who see some value in the overall neighbourhood-level improvements that accompany gentrification (Freeman, Braconi 2004; Sagan, Grabkowska 2013; Kovács, Wiessner, Zischner 2013). Perhaps this is because, like the group of middle class gentrifiers (Butler, Robson 2001; Butler 2007), the working class is also a heterogeneous group. Even so, Bernt and Holm (2009, p. 312) caution that "for the urban poor, gentrification means rising costs of living, the destruction of their social networks and the risk of being evicted". Accordingly, Davidson (2008) upholds that the initial welcoming of gentrification by local residents is temporary: as the negative consequences accelerate over time, opinions turn negative and residents are displaced. This displacement allegedly takes place in two manners: First, as gentrifiers proceed into their next life stage, they are likely to spill over the walls of their newbuild developments into neighbouring areas, buying out or pricing out their residents. While this is a conceivable development, it contradicts Davidson's (2007) own concern about the absence of meaningful connections between newbuild residents and their surroundings. Second, even before physical displacement sets in, the "indigenous" residents are likely to experience "displacement" (Davidson 2008), which approximately stands for the loss of sense of place caused by the increasing presence of elements that transform the social and cultural character of the neighbourhood, a "phenomenological relocation into a new urban social context" (Davidson, Lees 2010, p. 405) that gives it a "colonized and unfamiliar" (Davidson 2010, p. 540) ambiance. Consequently, social mixing remains limited and social class differences are reinforced: Davidson (2010) thus concludes that "we must avoid benign diagnosis" (p. 541). This diagnosis patently "evicts" many other processes of urban social change that may influence a neighbourhood's sense of place, e.g., the ageing population, international immigration or the overall restructuring of retail organization. It also implies that non-gentrifying neighbourhoods are static entities where time has stopped and life never changes.

For critical scholarship, newbuild gentrification, or any gentrification, is thus at best a zero-sum game in which the local non-gentrifiers are the losers 
because of their inevitable displacement, be it real or perceived. For the "lessthan-critical" (Freeman 2008), the process and its consequences are far more context-dependent, resulting in more or less desirable outcomes, most of which involve little or no displacement. For example, the frequently asserted role of the public authorities as major promoters of gentrification (Hackworth, Smith 2001; Smith 2002; Bernt 2012) needs to be gauged against the particular demographic, economic and political realities present in different cities and countries (cf. Rose 2010; Doucet, van Kempen, van Weesep 2011; Lemanski 2014). Importantly, Hamnett (2009) notes that the numerical expansion and professionalization of the middle class in London goes a long way in explaining the social upgrade that has characterized the inner city over the last few decades. Replacement, rather than displacement, would explain much of the rest: after all, selling a house is often a post-mortal event. Self-evident as Hamnett's arguments may appear to be, they have been met with ardent resistance from the clique of critical scholars, most vocally Slater $(2009,2010)$ and Wacquant (2008), who see such arguments as tools aimed at "evicting critical perspectives" (Slater 2006) from gentrification research in order to provide new space for global capital accumulation and, in particular, to facilitate Richard Florida's mission to re-attract the (gentrifying) creative classes to the city (see, e.g., Florida 2002). While part of this critique rests on its different interpretation of displacement (see above), it also contains challenges of an empirical nature. Slater (2010) contends that Hamnett's analysis is flawed on the basis that the standard classification of occupations (the so-called ISCO categories) disguises members of the working classes (including lower service classes) by incorrectly classifying them within higher socio-occupational groups. Wacquant's (2008) critique goes one step further by suggesting that the shrinking size of the working class is in fact illusory, being caused by "deepening divisions of skills, employment status and reproduction strategy, as well as by spatial scattering" (p. 199). This is Marxist talk at its best: class divisions orchestrated by someone else prevent the proletariat - this is the term Wacquant uses - from defending its own interests. Therefore, gentrification research should "revive and revise class analysis to capture the (de)formation of the postindustrial proletariat and inscribe the evolution of 'revitalized districts' within the overall structures of social and urban space and their linked makeovers" (p. 203). Of course, what Wacquant, or Slater, might not be aware of is the fact that the noble art of state-led gentrification had already been mastered by architects, planners and bureaucrats in state socialist countries from the 1930s and onwards (see Hegedüs, Tosics 1991; Sýkora 2005; Chelcea 2006, on the concept of "socialist gentrification"). ${ }^{3}$ How else are we to interpret the prominent Stalin-era neobaroque apartment complexes that are scattered across central Moscow and which rise on land that was previously settled by the poor who found themselves forcibly displaced (Bater 1980)? Critical thought may well be a solvent of doxa (Wacquant 2004, p. 101), but we must turn elsewhere to find a more helpful example of it. In the meantime, it may be to noted that if critical perspectives indeed have faced eviction from gentrification research, as fervently argued by

As Chelcea (2006, p. 127) notes: “[...] the bureaucratic allocation of state property regime, rather than market forces, can also create gentrification." 
Slater (2006) and others (Wacquant 2008, Bernt, Holm 2009), then at least the field of newbuild gentrification has become overwhelmed by squatters.

\section{Gentrification in post-Communist countries}

Gentrification in post-Communist countries must be understood against the backdrop of the social, economic and institutional transformations of the 1990's. As Sýkora and Bouzarovski (2012) suggest, the logical order is that deep-going urban transformations follow later. This includes gentrification, which did not appear to take off until the well after the new millennium had started, with the exception of a limited number of areas within very few major cities at the forefront of post-Communist change (Sýkora 2005), most notably Moscow (see Vendina 1997 and Badyina, Golubchikov 2005) - a city with a relatively large pool of potential gentrifiers because of its sheer size (Hamnett 1991). Gentrification did not evolve as rapidly at the next level of the urban hierarchy (Prague, Budapest, Warsaw) until much later, even though the economic potential (i.e., the rent gaps) for this to occur had been noted almost immediately (Sýkora 1993). If anything, the development and pace of change in the social structure of the residents of inner city areas during the 1990s was slow and produced mixed results (Kovács 1998, Dingsdale 1999). Instead, "functional gaps" (Sýkora 1993) were closed almost overnight, as this did not necessarily require significant investment and was not subject to the economic and legal framework that surrounded housing. Accordingly, commercialization and the creation of office space impacted most visibly on inner city areas (Sýkora 1999), giving them a flavour of commercial gentrification that was only marginally accompanied by changes in the social structure of their residents (and these changes may well have been both upward and downward, cf. Kovács 1998). The little residential gentrification that did exist had a distinct "expat" character (Sýkora 1999).

The crucial game changer came around the late 1990s (though later in Georgia). By that time, with all of the major institutional reforms in place and most post-Communist economies having recovered from the most acute period of economic crisis (Sýkora, Bouzarovski 2012), long-term mortgages at low interest rates coupled with improved living standards increased the number of people that were able to play an active role in the real estate market. However, while this technically facilitated gentrification, it also prompted a synchronized expansion of all of the main trends of post-war Capitalist urban development, at a time of rapid demographic transformation towards a society with fewer children, more elderly, and an increased number of households (Steinführer, Haase 2007). More than gentrification, in East Central Europe and the Baltics this meant suburbanization (Hirt 2007, Ouředníček 2007), and the (non-gentrifying) repopulation (reurbanization) of previously neglected inner city quarters (Kabisch, Haase, Haase 2010). The lifestyle offered by gentrification was thus forced to compete with alternative housing models, and suburbanization is the clear winner because it offers what residents of the post-Communist lack the most: space, modern dwellings and immediate proximity to recreational environments (Tammaru 2005, Ouředníček 2007). Instead, "traditional" gentrification satisfies the demand of a niche, and this 
niche appears to prefer established well-reputed areas (Sýkora 2005, p. 99), which casts some doubt on the effectiveness of the concept to describe residential change in the post-Communist inner cities.

However, the "sugarcoated" version of gentrification is increasingly being supported in the form of urban revitalization or regeneration programmes, and new housing construction is actively encouraged. The strategies vary somewhat, but they are largely based on the state or local authorities assuming the role of market facilitators (Sýkora 1999, Murzyn 2006, Temelová 2007, Bernt 2012, Holm, Marcińczak, Ogrodowczyk 2015) - critics fear that this makes urban land markets "turn into playgrounds of the agents of neoliberalism" (Nagy, Timár 2012, p. 124). Put differently, post-Communist cities jump-started their gentrification experience from the third wave (Hackworth, Smith 2001). The reason for this relates to the fact the inner cities really are in need of substantial investment in view of the very poor state of the housing stock left behind from the Communist era (Sýkora 1993; Szelényi 1996; Murzyn 2006; Nagy, Timár 2012). This is coupled with the continued presence of the socialist-made housing shortage, which means that latent demand for new housing is significant.

And indeed, newbuild developments have made their entry, not only in the city centres, but also in the socialist-era housing estates, "colonizing" the entire urban territory. Despite this, the process is not nearly as controversial in Central and Eastern Europe as it is in the UK or the US (with the notable exception of Berlin, see Bernt, Holm 2009). For the one part, it does not appear to cause much displacement, ${ }^{4}$ and for the other, any form of displacement (meaning loss of sense of place as in Davidson 2008; Davidson, Lees 2010) is made irrelevant by the complete phenomenological capsizing of place in postCommunist urbanism since the demise of the previous system. Also, perhaps, the residents of post-Communist inner cities have more to win and less to lose from gentrification than their established capitalist counterparts. After decades of disinvestment, and inspired by ideology (Szirmai 2006, p. 28), the socialist economies had brought major parts of the "bourgeois" city cores into a state of nearly hopeless dilapidation, creating the conditions for a gargantuan rent-gap (Sýkora 1993; Nagy, Timár 2012). ${ }^{5}$

As shown by the literature reviewed in the previous section, the themes of displacement, social mixing versus social contacts, and quality of life (including social cohesion) have permeated the most heated debates on the effects of gentrification. These are all relatively new themes in relation to the case of post-Communist cities, but a growing number of contributions has given

4 Where displacement does occur, it is often linked to specific prioritized urban regeneration projects aimed at either enhancing the potential for tourism or at improving very poor housing conditions, or both (cf. Murzyn 2006; Nagy, Timár 2012).

5 This is somewhat different in the more authoritarian countries, where urban regeneration is often associated with grand projects and grand displacement (e.g., in Baku, see Darieva 2011 and Valiyev 2013). Unlike the case of the more modest flagship projects that have appeared across Central and Eastern Europe and which may have a radiating regenerating effect (Temelová 2007), urban regeneration in (particularly capital) cities located in countries led by autocratic leaders, tend to have an uncompromising bulldozer approach (Koch 2015). 
some indications that can be used to assess the applicability of "Western" gentrification theory.

Kovács, Wiessner, Zischner (2013, and also this issue) suggest that there is limited evidence of direct displacement in Budapest, despite the significant upgrading of the built environment, coming to the conclusion that gentrification, as part of the overall urban regeneration of Budapest, is considerably softened by the large size of the owner-occupied sector (a result of so-called give-away privatization), rather than by housing oversupply and regulation, as is the case in the former German Democratic Republic (cf. Garcia-Zamor 2014, ch. 8 and 9). Indeed, and as suggested by Sýkora (2005) based on the experience of Tallinn, Budapest and Prague, restitution policies probably have a stronger influence on the development of gentrification than does privatization. Where restitution has been absent (e.g., in Poland), gentrification has evolved more slowly (Marcińczak, Sagan 2011), and the main changes in inner city population structure appear to be caused by replacement rather than displacement, coupled with professionalization (Sagan, Grabkowska 2013; cf. Hamnett 2009). However, sites of exceptional touristic value (for example, the old towns of Prague, Cracow, Tallinn and Riga) have experienced rapid transformations that include the substantial loss of residential functions and a strongly gentrified residential residual (Murzyn 2008; Temelová, Dvořaková 2012).

The experience of the Hungarian capital appears to be in striking contrast with the findings from three smaller cities in Hungary, Poland and Romania, respectively, where gentrification appears to have been all but soft. Based on the experience of state-led gentrification (or slum-clearance) in select inner city areas, Nagy and Timár (2012, p. 129) recognize the impacts of the global spatial logic of capitalism, thus aligning themselves with the narrative of gentrification as a global strategy that has inspired the works of critical scholars since the turn of the millennium. In relation to their most detailed case study, they conclude that "what happened in Veszprém proves that it is the global interrelationship between gentrification, segregation and displacement that we can identify". However, it is important to note that the particular cases studied by Nagy and Timár refer to locations where the "housing conditions [...] were miserable and affected the residents" (p. 128), representing the conceptual colonization of slum-clearance by gentrification research. ${ }^{6}$ Accordingly, the authors' interpretation of these experiences through the lens of mainstream ("evicted") critical theory might represent the loss of a valuable opportunity for bottom-up, Veszprém-up, theorization (rather than London-down). Here, Lemanski's (2014) hybrid gentrification gives us an indication of the direction that could be taken, even though the concept itself is not applicable in this

6 There are important moral considerations at stake here: most importantly, if private funding - with or without support by public authorities - actually helps improve the housing conditions at the cost of relocation (displacement), does it not have a value in itself? Certainly, the slum clearance rhetoric is often used as an excuse for gentrification (Simon 2011), but the expansion of gentrification into this realm has its limits because any project that involved demolition - whether justified or not - will inevitably cause at least temporary displacement (even when displacees are promised new residences at the same location, the entire project may take years to complete, by which time the existing community structures will have broken down anyway). 
case. What appears to make the Veszprém case particularly interesting is the overlap between what appears to be a necessary renewal of the housing stock and a not-so-admirable ambition to redraw the ethnic map of the city, at the expense of the Roma community residing in it.

While most research that touches on gentrification in post-Communist countries suggests that the inner cities remain socially mixed, the nature of the mix has changed somewhat. In this respect, it is noteworthy that many of those who are often viewed as gentrifiers (young middle class professionals, students, etc.) in "Western" theory are in fact in a completely different position in postCommunist countries. Unlike their parents' generation, they have usually not benefited from housing privatization, and their predicament is thus similar to that of the tenants of restituted formerly nationalized property. However, unlike the latter, most "gentrifiers" were unable to enjoy the benefits of (temporarily) protected tenants' rights, either. They are, in effect, the first group to be fully exposed to the rules of the free market.

A central feature of all conceptualizations of gentrification is that the new residents should come from a higher social class than that of those whom they have displaced, replaced, bought out, or priced out (Hamnett 1991; Hackworth, Smith 2001; Slater 2009). With the notable exception of the Prenzlauer-Berg in Berlin (Bernt 2012) and of the super-gentrified Ostozhenka neighbourhood in the Global-City sized Russian capital (Badyina, Golubchikov 2005, cf. Butler, Lees 2006), the little research that has been conducted in European postCommunist states does not indicate that this is a major trend. Instead, the inner cities appear to be attracting young cohorts with mixed (including low-end) incomes and varied social backgrounds (Haase, Grossmann, Steinführer 2012; Kovács, Wiessner, Zischner 2013; Sagan, Grabkowska 2013) - a group that does not necessarily plan to remain in the city centre for long, and which has been described as "transitory" by Haase, Grossmann and Steinführer (2012). As in the case of Bristol (Bridge 2006), the size of the pool of gentrifiers does not seem to be sufficient to support an infrastructure that would allow the gentrifiers to remain in the inner city after entering their next life cycle stage. In this sense Moscow and London have more in common than Moscow and Ufa. Interestingly, however, there are indications that gentrification may even lead, in some contexts, to an increase in neighbourhood social ties and social cohesion (Sagan, Grabkowska 2013), which strongly challenges the narrative of insurmountable social distance that transpires from research conducted in British cities (Davidson 2008, Doucet 2009). Sagan's and Grabkowska's findings suggest that social mixing is actually strengthened due to the reluctance of established residents to move, coupled with the awareness and appreciation of the local social context exhibited by the gentrifiers. ${ }^{7}$

Our review of the literature on gentrification in post-Communist cities indicates that the current state of the art in research has three main characteristics: (a) it suggests that post-Communist gentrification is a mixed and

7 One particular group of established residents are the elderly, for whom gentrificationinduced neighbourhood transformations may be expected to cause increased economic hardship. However, a timely study by Temelová and Dvořáková (2012) suggested that the evidence for this contention is mixed. 
relative small-scale phenomenon, (b) it assesses its findings in relation to a theoretical framework developed elsewhere (in the West), and (c) it ignores most of the post-Communist world, including its own "South". The remainder of this paper will engage with each of these points by exploring Tbilisi's experience of newbuild gentrification.

\section{The Tbilisi context}

Our case study, the Georgian capital city of Tbilisi, displays most of the characteristics typical of the metropolis of the post-Communist South: (a) a context of incomplete urbanization, (b) temperate climate, (c) relatively weak institutions, (d) a permissive and poorly enforced planning context, and, concomitantly, (e) a high degree of informal and illegal construction activities (see Bouzarovski, Salukvadze, Gentile 2011).

Torn apart by both violent conflict and economic turmoil, Tbilisi has embarked on an urban transformation process that has preceded many of the reforms often associated with market transition, such as the formation of a coherent and stable planning system (van Assche, Salukvadze 2012). Therefore, it does not concord with the logical chronology of transformation suggested by Sýkora and Bouzarovski (2012).

With almost 1.2 million inhabitants (2015), Tbilisi is Georgia's primate city, having grown rapidly during the years of Soviet power, reaching the one-million mark by 1974 and exceeding 1.25 million in 1989 . During the $1990 \mathrm{~s}$, the population dropped by 15 percent as a result of out-migration, internal civic tensions, ethno-political conflict and general economic turmoil. Sustained emigration to countries with higher incomes gradually produced a significant Georgian diaspora population, and, as this paper will show, the latter influences investment in the city's real estate sphere in a way that is somewhat reminiscent of the role of wealthy magnates from the Middle East or Russia in the UK newbuild market (cf. Boddy 2007, Edwards 2011). Meanwhile, the city absorbed substantial numbers of internally displaced persons (IDPs) from the conflict regions of Abkhazia and South Ossetia (Salukvadze, Sichinava, Gogishvili 2013; Kabachnik et al. 2014). Today, this vulnerable group numbers approximately 100,000 persons (2015). The negative population trend was reversed in the 2000 s, owing to in-migration from rural areas and smaller cities. An additional increase in population resulted from the new flows of IDPs generated by the 2008 Russo-Georgian war. Accordingly, Tbilisi has experienced substantial urban growth, generating new demand for agonizingly short-supplied housing which has been met by newbuild construction and a sui generis expansion of existing dwellings (Bouzarovski, Salukvadze, Gentile 2011). The housing shortage should be understood not only in light of the demographic pressure that it is subject to, but also as a reflection of the rapid depreciation of the Soviet-build stock, which is increasingly obsolete and frequently beyond repair.

Tbilisi was relatively prosperous under socialism. With the Soviet-era economic links with the rest of the Soviet Union having been severed following the demise of central planning, the city lost much of its former economic strength, and most of its industrial enterprises were idle. The ensuing crisis, 


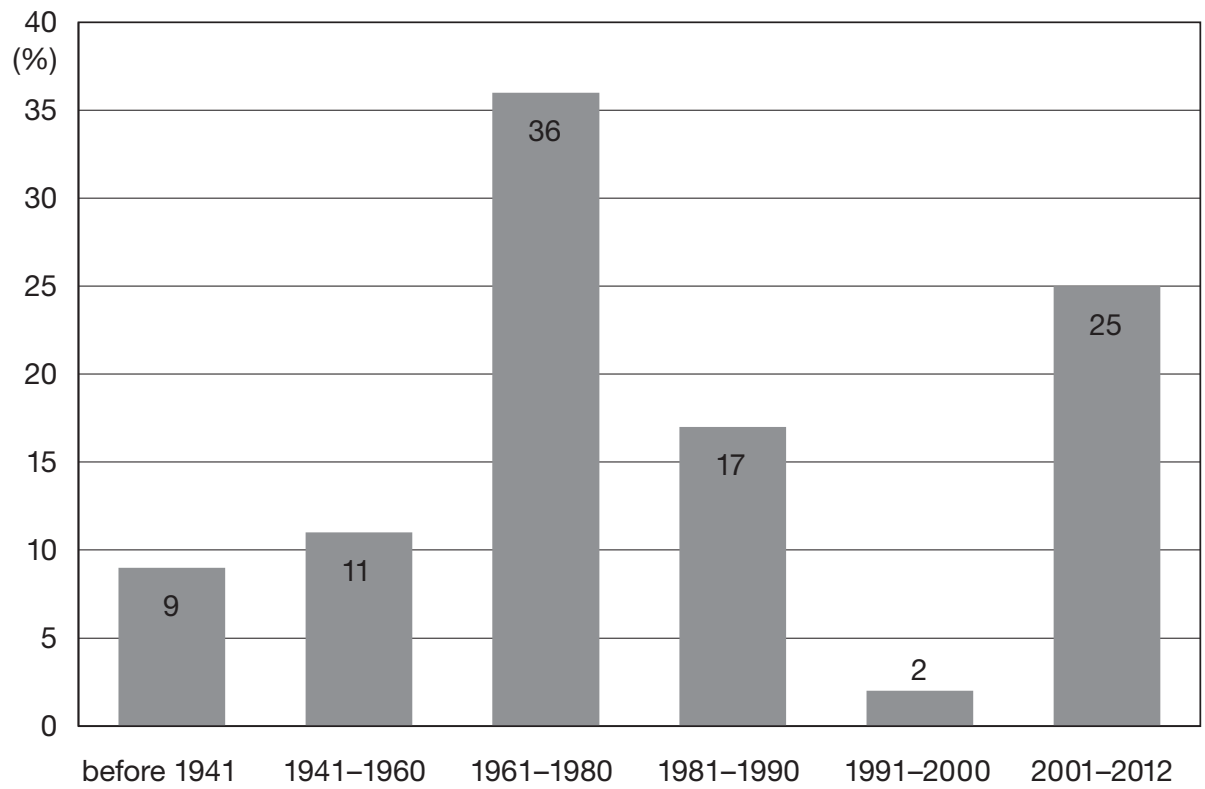

Fig. 1 - Distribution of the Tbilisi housing stock by period of construction. Source: Jones Lang Lasalle (2012).

as elsewhere, was accompanied by hyper-inflation, which eroded most of the population's savings. As a result, the population's living standards plummeted; it took no less than a decade for the situation to start improving again.

These broad socio-economic changes are reflected in the development of the city's housing stock (which consists of nearly 340,000 units with a total surface of $30.2 \mathrm{mln} \mathrm{m}^{2}$; see Jones Lang Lasalle 2012). More than half was produced between 1960 and 1990 using mass production technologies (Fig. 1). While the dwellings erected during this period came with all modern (by Soviet standards) conveniences (kitchen, bathroom), the quality of the buildings is generally regarded as low (cf. French 1995).

With the withdrawal of the state from the housing supply, the production of new dwellings came to a halt in the 1990s. Construction boomed again after the turn of the new millennium, only to collapse with the onset of the global economic crisis and following the war in 2008 (Fig. 2). If almost one quarter of the current housing stock stems from the 2000s, the buildings that have been completed in the 2010s are often resumed projects that had been interrupted by the sudden crash in 2008. In general, the construction business involves small-to-mid-sized and mid-sized domestic enterprises, with a handful of larger actors being present - but not dominant - as well. While the volume of construction during the 2000s did not reach the levels achieved during the heydays of socialism, the output was better - but not necessarily good - in terms of interior quality, comfort and design. Accordingly, ceteris paribus, the square metre prices for apartments in newbuild developments are well above those found in the Soviet-era structures surrounding them, and buyers typically earn 


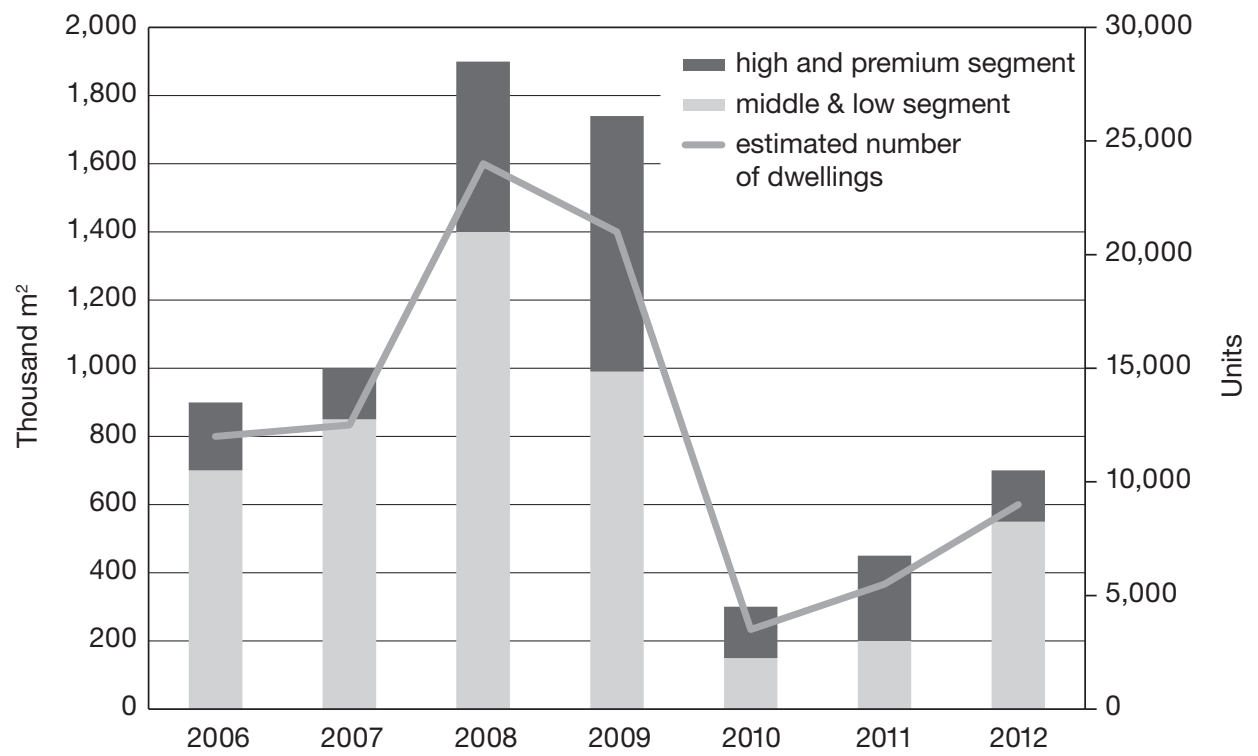

Fig. 2 - Volume of sold residential space and number of units in Tbilisi, 2006-2012. Source: Jones Lang Lasalle (2012).

higher incomes when compared to their neighbours living in Soviet-era apartments. In the near-absence of "classic" gentrification (bar the controversial state-led efforts to refurbish and recreate the city's Old Town, see, e.g., the Economist, 6 October 2010), newbuild developments are thus the most palpable form of gentrification in Georgia because they typically introduce upper-middle and upper class groups into neighbourhoods characterized by residents with relatively lower or mixed social status. In other words, this conforms to what is known as newbuild gentrification among critical scholars from the Global North (Davidson, Lees 2005, 2010; Stabrowski 2014).

The housing construction statistics for the period surrounding the most recent crisis (Fig. 2) reveal a one year lag between the onset of crisis and its reverberations on the housing supply. This is explained by the fact that the apartment purchases are usually made in several tranches, meaning that the finalization of the transaction, as well as property registration, usually took place the year after the completion of an object. Together with a striking decrease in the volume of sold housing space after the crisis, there has been a remarkable increase in the share of the high and premium quality segment during recent years.

The central parts of the city, particularly on the right bank of the river Mtkvari are the ones that have attracted most newbuild investment. They are also the city's historical focus of prestige - as opposed to the peripheral housing estates in the south-eastern part of the city and to the more dilapidated parts of the inner city - supporting Sýkora's (2005) suggestion that post-Communist gentrification targets existing "good addresses". Accordingly, newbuild gentrification in Tbilisi would appear to include an idiosyncratic 
element of "super-gentrification" (Butler, Lees 2006). Table 1 reports the volumes of construction, for all uses, for which Tbilisi City Hall has issued building permissions between 2005 and 2012. While this does not say much about actual construction (for which we have no data), it indicates which particular urban districts are most sought after by the developers: Vake-Saburtalo and Old Tbilisi. These two districts roughly represent the inner city, but it is the already densely built-up Vake-Saburtalo that has attracted the greatest volumes of planned or built developments - almost half of the entire city's - and we may assume that the residential function prevails. Substantial relative growth is also signaled in suburban-like Didgori, where a vast gated community project strongly influences the permit statistics for 2008. Nevertheless, newbuilds have been erected or are planned across the entire city, partly reflecting the geography of available vacant or underexploited land. Seen through Davidson's (2007, p. 503) lens, this would imply that newbuild gentrification in Tbilisi, like in London, takes place in the form of a rapid colonization rather than by through the advancement of a creeping frontier (see Table 1).

\section{Research materials and methods}

Our study is composed of three separate interview studies. The first study targets real estate professionals, specifically managerial staff of developer businesses $^{8}$ (12 interviews) and real estate agents (3). The second study was conducted among residents of newly erected residential developments, i.e., among the group that the literature considers to represent the class of "newbuild gentrifiers" (20). The third study interviewed non-gentrifying "locals" (10) among residents of the immediate neighbourhood of the newbuilds erected by the businesses whose representatives were interviewed for the purpose of the first study. The interviews with developers took place in spring 2008 , but the outbreak of war with Russia delayed the other two studies until 2009 and 2010, respectively, by which time the housing market had collapsed. All interviews were conducted by 19 carefully selected human geography Master's students from Tbilisi State University. The latter transcribed (and summarized, if

8 The questions that were posed to the developers were, as an absolute core, the following: (a) How much residential space are you currently constructing? (b) Which parts of the city do you focus on, and on which grounds? (c) Do you offer off-plan sales (i.e., before the construction is finalized or even started)? (d) What factors affect the prices the most? (e) How long are your construction times, and what factors (if any) have been causing delays? (f) Do you offer any form of compensation in the case of delays? (g) What kind of final product do you generally deliver (black frame, white frame / shell-and-core or ready-tomove-in/turnkey)? (h) For which social groups do you build, and where do your buyers typically reside? (i) What is your current price range? (j) What kind of contacts do you maintain with the state institutions, and especially the City Hall (to get building permits, submit project proposals, etc.)? (k) Do you think your business requires personal connections with government officials? (j) Do you have any kind of formal or informal cooperation with credit institutions?

9 Whether or not this group really does live up to the criteria that define newbuild gentrification is highly debatable. 


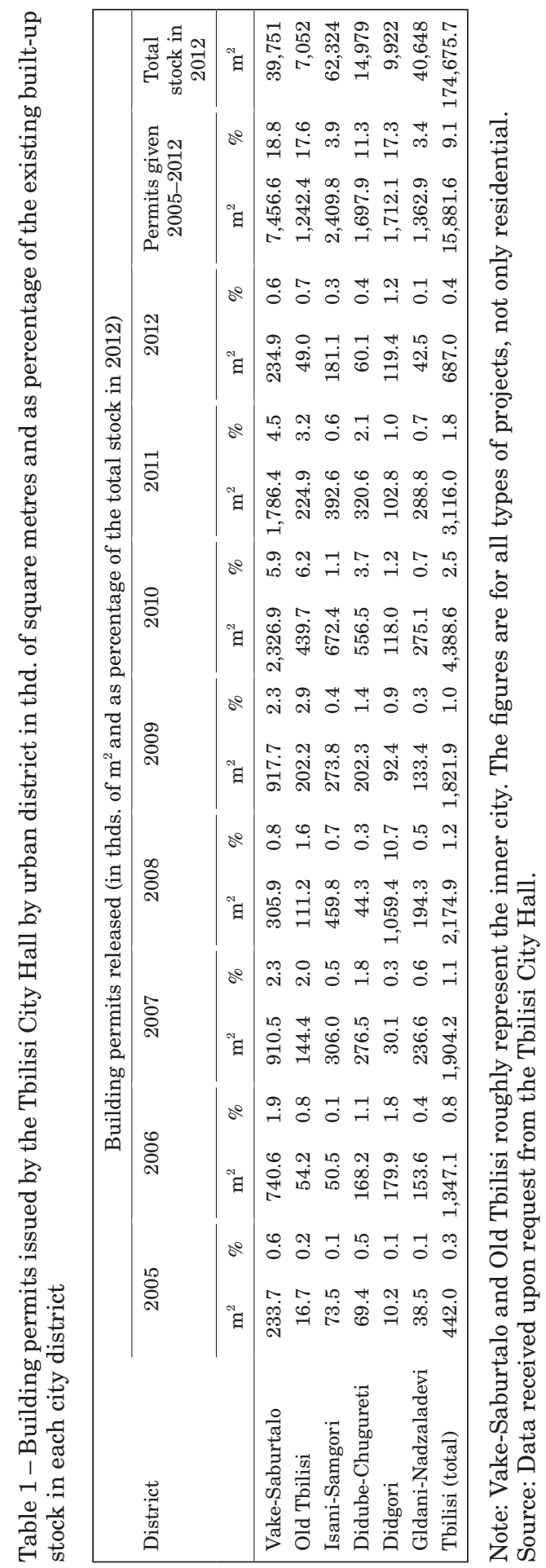


necessary) the interviews, but the responsibility for the analysis and interpretation of their contents rested on the authors. ${ }^{10}$

The interviews with the developers were structured and aimed at factfinding, but they were open for contextual and topical adjustment when needed. Although one may fear the presence of vested interests in the developers' responses, it is important to recall that gentrification and new housing construction in general are not considered to be particularly controversial in Georgia. Tbilisi is rapidly growing and there is an acute housing shortage that only promises to get worse at the current rate of decay within the Soviet-built housing stock, not least because there is no (openly publicized) city government strategy regarding this. The interviews with the newbuild gentrifiers and their veteran neighbours were semi-structured, following a pre-defined discussion guide covering a number of themes relating to their experiences as buyers and newbuild neighbours and in relation to the overall transformation of the neighbourhood's environment.

The character of the study is explorative, and the nature of the material (as indeed of any interview material) does not allow us to make generalizations, but it enables us to raise a number of recurrent themes that allow us to gain important understanding of the phenomenon of newbuild gentrification in Tbilisi (and of the Georgian housing market more generally), to which we now turn. Currently, newbuild gentrification and similar processes cannot be investigated quantitatively, as the necessary data have not been released.

\section{Newbuild gentrification and tele-urbanization}

From the beginning of the new millennium and roughly until somewhat before the August 2008 war with Russia over separatist South Ossetia and Abkhazia, residential construction increased conspicuously in Tbilisi. At that time, the assessments of the future of the Tbilisi real estate market among the interviewed developers were overly optimistic. This was in part supported by the observation that the actual size of the market was expanding because of its gradual absorption of the middle social strata, who relied on recently available relatively soft and affordable bank credits, as well as on foreign remittances. In fact, if the typical buyers of the early 2000 s mainly consisted of members of

10 The sample for the interviews among developers can be described as a geographically stratified convenience sample: the city was initially subdivided into seven sectors in accordance with the territorial classification scheme used by the developers themselves. The interviewers were asked to identify all newbuild projects and to enter into contact with one or two developers within each sector. The latter selection was a matter of convenience: although a more strict sampling process would have been preferable, we do not have access to any reliable sampling frame and, especially, the response rate would have likely been low, meaning that the outcome would have been similar to that of a convenience sample. The interviews conducted for the second and third studies were based on convenience samples in relation to the objects (developers) selected in the first study. In this case a random sample (e.g., a so-called random walk) would have been feasible but rather unnecessary given that qualitative interviews do not build on the assumption of statistical representativeness. 
privileged groups - higher bureaucrats, politicians, successful businessmen, artist elites and one or other criminal element - by 2006 they started including members of the middle and upper middle income segments, and occasionally even of the lower middle income group. However, with the onset of the global financial crisis, by 2009 the middle income strata had again largely evaporated, owing to the combination of the credit crunch and of the decreased flow of remittances from abroad. Also, while remittances are assumed to have played an important role in the financing of real estate purchases throughout the first decade of the millennium, their relative share was never fully dominant, being estimated at approximately 40 percent when it was at its highest (in 2006) and receding to about 20 percent after the war. The latter decrease is largely attributable to the sudden loss of Russia as a source of remittance money (see O'Hara, Ivlevs, Gentile 2009), as well as to the economic contraction in many European countries and in the United States.

Until the war, the preferred locations for investment were in the central parts of the city, but the situation changed during the second half of the $2000 \mathrm{~s}$, with more and more peripheral locations (also) attracting investment. From having been a localized inner city phenomenon, newbuild infills started "colonizing" an ever-increasing number of semi-peripheral and peripheral locations. The interviewed developers unanimously declared that the profit margin in centrally located areas such as Vake, Vere and Saburtalo - areas that were already appreciated during the years of Soviet power - was simply greater (cf. Sýkora 2005, on the "gentrification" of already prestigious addresses). As the director of one real estate development firm noted, construction costs on the most expensive inner city land were of about 800 USD per square metre, but premium locations in Vake were able to yield up to 2,500 USD per square metre - quite a profit margin, reflecting the presence of a substantial rent gap. This compares to sale prices of about 700 USD per square metre on more peripheral sites. In the absence of a developed mortgage credit market, both price levels are beyond the reach of most residents of Tbilisi which explains the tendency noted by most developers, i.e., that wealthy Georgians residing abroad stand for a large share of the purchases, perhaps over one third of the total. For many people, and most notably for the Georgians residing (or having resided) abroad, buying property in Tbilisi was seen as an investment intended to capitalize on future price hikes. As a result, many newly built (and sold) apartments remained vacant, in a manner that is vaguely similar to the effect of Overseas buyers in British cities (Boddy 2007). In other words, if gentrification is defined by the physical presence of gentrifiers (Beauregard 1986, Hamnett 1991), part of what looks like newbuild gentrification in Tbilisi is in fact an entirely different phenomenon - less social and more physical. It is a process of remotely controlled urbanization which we may refer to as tele-urbanization. Alternatively, we could conceive this phenomenon as of tele-gentrification, if the newbuilds were to demonstrate any kind of "genuine" spill-off gentrification by influencing the value of their neighbouring territories. 


\subsection{Crisis and post-crisis situation}

The positive expectations from before the war turned out to be overly optimistic. Since 2008, prices have fallen sharply and the demand remains at a stand-still, despite some recent positive signals. Assessments of the price drop range from 20-40 percent (depending on the neighbourhood) to a more generalized 25-30 percent. Moreover, the banks' lending policies have become far more conservative, influencing both supply (minimal access to building credit) and demand (minimal access to the mortgage credit market). As a result, most of the projects that were not completed by 2008 have been left incomplete, and many of the objects that were completed did not find any buyers, despite significantly lower prices. Georgians residing abroad became the single largest group of buyers, in relative terms, which suggests that tele-urbanization (though for sure not tele-gentrification, due to the market's standstill) became the dominant force within the depressed market for new housing.

It should be noted that because tele-urbanization implies an increase in vacancy rates, it might slow down the future rate of housing construction once the market recovers. After all, at some point, buyers who do not have the intention or the opportunity (whether in the short or long term) to occupy these dwellings will probably want to capitalize on their investments, increasing the supply of almost-new apartments.

In a follow-up interview with the director of the CID Architects development firm in May 2011, it was noted that the situation improved gradually starting in 2010. During that year, the Tbilisi municipality moved to inject confidence in the market by guaranteeing the purchase of all finished objects at the price of 400 USD per square metre, thus guaranteeing partial or full cost recovery - or even minimal profits - for the developers. While this very low price did not result in any significant amount of transactions involving the municipality, it did loosen some of the tightest knots in the credit market by lowering the banks' perception of risk, thereby stimulating their willingness to lend. This encouraged the developers to resume at least some projects, which were then sold off at square metre prices of 600-700 USD or higher - a far cry from the spectacular pre-crisis market prices. Accordingly, the number of vacant new apartments has started to decline, while residential property prices have slightly increased. Even so, the number of unfinished objects remains high, and there are no signs of a true and imminent real estate market take-off. The Tbilisi municipality's actions are consonant with the "third wave gentrification" notion of state promotion and state involvement in the gentrification process (Hackworth, Smith 2001; Smith 2002; Bernt 2012), though with a significant twist. Whereas the textbook case implies that the state takes a leading role in facilitating and/or initiating gentrification(-like) processes (cf. Bernt's 2012 study on Berlin and Harlem, NY), in this case its main interest is the survival of the process. However, rather than achieving a specific social goal such as the class-remaking of a particular area, the Tbilisi municipality's main interest is very basic: it wants to prevent the lingering of unfinished eyesores that was a chronic malaise of the Soviet city (cf. Asslund 2002).

New apartments are typically built on infill sites in the central parts of the city. Often, these sites are very small, creating very high building densities, 


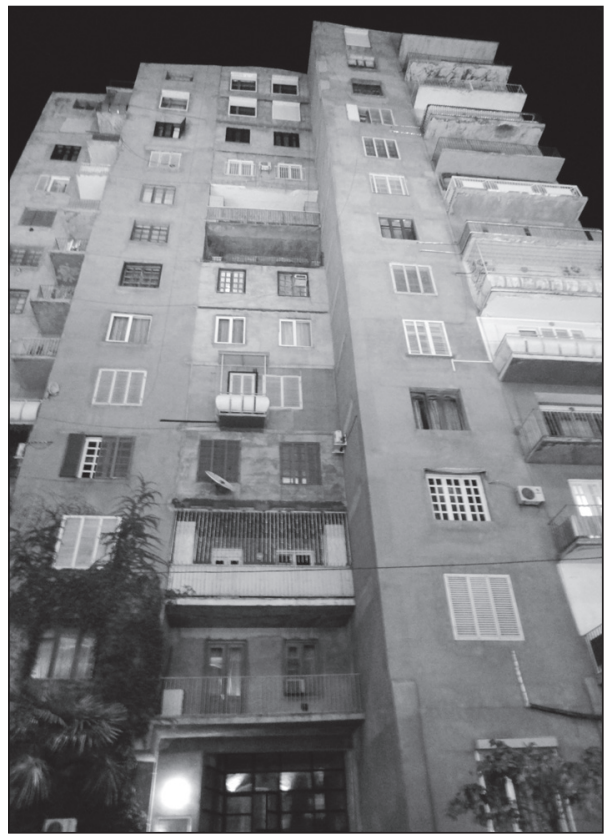

Fig. 3 - Eclectic solutions in a recently built white frame building in central Tbilisi. Photograph by author. both horizontally and vertically (see Fig. 3). The quality of construction is not always reassuring, even though most developers assure that, e.g., the seismic safety of their projects has been verified, either independently or by in-house expert staff. Because the buildings are usually infill developments, there is very little direct displacement. When displacement does occur, it is usually dealt with directly between the developer and the displaced, and some form of compensation, such as an apartment in the new development, is offered. This is facilitated by the fact that an overwhelming share of the housing stock is privatized. ${ }^{11}$

Residential space is typically provided by the developers at three different levels of completion: "black frame", "white frame" and "fully furbished". The black frame essentially only includes the floor, walls and ceiling, as well as the front door and the windows. The white frame includes most interior work, but it excludes the kitchen and bathroom furnishings and appliances, which are the extras included in the fully furbished product. As of recent, the white frame appears to prevail within the market, but all models have experienced cycles of popularity. Particularly the black frame option implies that the final product - i.e., once the settlers have left their personalized mark on the interior and even the exterior of the dwelling - is rather eclectic. While this may be a singularity of the Georgian market, it does suggest that the idiosyncrasies of newbuild gentrification in the post-Communist south contradict the critical narrative of the newbuild product being designed, produced and promoted entirely by big business with the aim of reproducing a real or imaginary globally connective lifestyle (e.g., Smith 2002, and especially Davidson 2007) - a narrative which sees individuals as passive consumers whose preferences and choices are narrowed down by the blinding appeal of safe city life and of the cynical brochures that manufacture

11 One notable exception concerns almost half of the internally displaced persons from Abkhazia and South Ossetia, i.e., those who are/were housed in so-called collective centres. The latter include(d) former hotels, kindergartens, schools, medical facilities, etc., many of which located on extremely valuable land. As time passed, many valuable objects were privatized and their residents subject to forced displacement, for which they received a compensation of 7,000 USD in the mid-2000s. The procedure has been highly disputed, not only with regard to the size of the compensation, but also because it shattered wellfunctioning communities (Manning 2009, Kabachnik et al. 2014). While this form of displacement is certainly important, it does not fall within the scope of this paper. 
this particular "habitat". In other words, the scope for individual expression offered by "black frame gentrification" is something that it shares with "classical" gentrification, indicating, once again, that when North-developed theories try to go global, their risk of being contradicted by reality rises.

The construction process is - or rather was - very dependent on the availability of credit, which was easily obtainable until 2008 given the high profit margins on almost all new construction. However, credit financing was typically used to buy attractive land for construction; the actual construction process was usually financed through off-plan sales (pre-construction), meaning that the buyers were temporarily "buying air"; the majority of dwellings were sold this way until the crisis started. Off-plan sales are particularly attractive to developers in volatile markets, as they reduce the time of risk exposure to fluctuations in the real estate market (Davidson 2007, p. 497) ${ }^{12}$ Reflecting this fact, pre-construction prices were always lower. However, with the onset of crisis, high vacancy rates and low market confidence levels eradicated the practice of "selling air" and bankrupted most credit-oxygenated construction businesses.

\section{Newbuild "gentrifiers" and locals}

\subsection{The gentrifiers}

The interviewed buyers of newbuild dwellings in the inner city included both long-time inner-city "locals" and former residents of peripheral housing estates, indicating that the newbuild gentrifiers - a term which appears to be misleading in this context - have different lifestyle backgrounds but a common desire to live in central areas. Overall, they had a positive appraisal of their new living quarters, and the developers appeared to have delivered approximately what was expected of them. The most frequently surfacing grievances concerned factors related to the lax planning regime: high density (and especially the height of the surrounding buildings) causing insufficient daylight, and poor aesthetics or architectural qualities. Of course, these are problems that the gentrifiers themselves contribute to.

Most respondents reported using their own savings to finance the purchase, often complemented by remittance money. Also, the relative ${ }^{13}$ ease at which mortgage loans were available during the mid-2000s explains the relatively high number of middle class novel home owners during this period (and not before or after). All told, the majority of the respondents were satisfied with the price-quality ratio of their purchases, although some former residents of demolished structures believed that the compensation they received (i.e., agreed upon) for their dwellings was inadequate.

12 Construction times typically averaged (according to the developers) 1.5 to 2 years for highrise apartment blocks.

13 The Georgian mortgage credit market was still not comparable to the one existing in most countries of the Global North, with higher interest rates and considerably shorter amortization times. 
In the majority of cases, the buyers started off in the off-plan market, thus putting a fair share of trust in the solidity and reliability of the developing companies. In some cases - particularly among recently repatriated or foreignresident Georgians - the purchase was seen as a safe and profitable investment or business idea. Because "air" was cheaper than brick-and-mortar, there was money to be made by buying the former only to re-sell it in solid state. As an example, one high-income respondent, a former eight-year US resident, purchased an apartment in the centrally-located Arsis Ubani complex before it was built, even though he had not yet decided whether or not to live there. After all, he already did own two apartments in the city, and his most recent real estate transaction was largely intended as an investment resting on the expectation of future (additional) price increases.

Such speculation notwithstanding, the main motivation for buying a newly built apartment is to improve the immediate living environment, particularly when compared with the poor conditions prevailing in Soviet-built apartment blocks. Accordingly, both the physical characteristics of the new dwellings and their locations tend to be more appealing. As one respondent put it, "the main thing is a safe and secure environment for my children ... also, we wanted to choose a place that was more conveniently located with respect to the children's school [...] in general, I'm fine with where we live now, but the family decided to move to Saburtalo - we're building [buying] an apartment there" (35, F).

This is a telling quote. In qualitative research on gentrification, "safe and secure for children", "conveniently located with respect to the children's school" and similar expressions are more likely to describe the reasons for leaving gentrified areas, rather than for moving into them (cf. Bridge 2006). However, in post-Communist cities, and particularly in the post-Communist South, the suburban and peripheral areas of urban regions are typically primitively equipped and poorly serviced. Thus, if the gentrified parts of the inner city of Bristol (Bridge 2006) or sometimes even London (Butler, Robson 2001) may be characterized by a deficient infrastructure for gentrification, which would allow child-rearing families to remain, a similar problem - but worse - exists within post-Communist suburbia. In short, Tbilisi families may choose to urbanize for the same reason as families in European or North American cities suburbanize.

\subsection{The locals}

New-build projects imply a series of microgeographical rearrangements at the neighbourhood level, including significant transformations of the physical and social environments. As in the case of "classical" gentrification, this means new residents, new facilities and, possibly, the displacement or upgrading of existing local services, particularly within the sphere of retail. Together with the potential effect of pricing out local residents, this may entail a "loss of place" as it was experienced by the established residents, i.e., a displacement of sorts (or displacement, see Davidson 2008 and Davidson, Lees 2010). This would lead us to expect an overall negative assessment of the newbuilds on behalf of the long-term residents. However, this was not the case: while the respondents' opinions ranged from very negative to very positive, positive appraisals were 
more frequent. In fact, most of our respondents showed little concern about the new developments. The major grievances were the disproportionate height and density of the projects, as well as their impact on the traffic and parking situation, and on air and acoustic pollution (due to increased traffic and/or poorer ventilation). In other words, the gentrifiers and the locals appear to have similar concerns.

Despite some critique, most respondents thus accepted the new building(s) together with their consequences, emphasizing that they improved the appearance of the area, making it look more organized. One informant told us: "investors often approach us offering to demolish our old houses and replacing them with apartments in the new buildings as compensation [...] Why should I refuse? I have three sons, a widower [...] They make the place better and more beautiful, they build better [...] Some complain about the noise? How could they build without making noise?" (52, M).

This is the kind of positive feedback that Davidson (2008) would dismiss as temporary (and possibly delusionary). Moreover, most informants declared that they would have been happy to live in the same building as their new neighbours, had they only been able to afford this. But not quite all of them. An elderly respondent expressed the following uncompromising critique: "they [the developers] start and can't finish; they don't care about anyone, not even old people. What if someone wants to sleep in the daytime? And where should the children play? They throw down all of the stones, the garbage, and no one takes it away, and then they bring sand in trucks, and when the trucks break down they just leave them there... so much dust. Look at how small our house is... and no one comes to apologize! Sure, I'd like an apartment there, but who will give it to us?" (67, M).

While devastatingly explicit, this critique is of a different kind than what we would often encounter with regard to gentrification in the Global North because it only focuses on the very tangible - albeit temporary - inconveniences associated with living next to a construction site, possibly for several years when several projects follow each other within the same street blocks. These are exacerbated by the fact that newbuilds are often erected on very small plots with little space for, e.g., scaffoldings or construction material storage. To some extent, this is a new phenomenon in post-Communist cities, as almost all previous construction took place on peripheral greenfield sites. None of our interviewees even mentioned the possible social or community-breaking consequences of the newbuilds. In short, our interview exercise with gentrifiers and locals did not reveal any evidence of social conflict arising from the ongoing process of newbuild gentrification. Perhaps this would mean that Tbilisi, like other cities in Central and Eastern Europe (Kovács, Wiessner, Zischner 2013, 2015; Garcia-Zamor 2014), is undergoing "soft gentrification", but the scale and spatial impact of the newbuild developments is such that it would strongly contradict this notion. Perhaps we are looking at a context where change takes place where change is expected: in Tbilisi, few would be appalled by the disappearance of the local retailers (as, e.g., Davidson, Lees's, 2010, respondents). There were no such stores until the early 1990s - and the moment in history that they represent is rather associated with chaos, poverty and "Global Southening”, as are the rapidly decaying Soviet-built apartment blocks. 


\section{Conclusions}

Gentrification theory - critical or not - stems from decades of scholarly engagement with the inner cities of the Global North. In a context of incomplete urbanization and rapid "post-Communist" societal and urban transformation, contemporary understandings of the process are seriously challenged. In Tbilisi, the effects of urbanization, of remote-controlled investment in construction by members of the diaspora, and of the serious housing shortage inherited from the Soviet period, combine to create a highly dynamic and elusive pattern of urban transformation, particularly in neighbourhoods with an established reputation of prestige. The visual outcome of these processes conjures an image of newbuild colonization in accordance with the global script of neoliberal thirdwave gentrification (Hackworth, Smith 2001; Smith 2002), and Tbilisi would appear to deserve being added to the swelling list of worldwide cities that have become the victims of this unstoppable force. However, this image misrepresents a complex reality where the residential spaces of the city develop at the volatile intersection of Soviet heritage and market transformation (cf. Golubchikov, Badyina, Makhrova 2014), all glazed with the additional distinctiveness of the Georgian experience of laissez faire urban planning (Bouzarovski, Salukvadze, Gentile 2011), recurrent political turmoil and armed conflict. Within this capricious setting, there certainly is also space for both classical gentrification and globally scripted newbuild gentrification, but, as in many other cases in Central and Eastern Europe, these phenomena are not an important - let alone defining - characteristic of the intense process of newbuild residential densification that is taking place in Tbilisi. Therefore, with this in mind, how can we conceptualize the developments that have occurred in the city over the past dozen years?

The existing language of gentrification, including its "sugarcoated" aliases reurbanization and the like - is not sufficient for two main reasons: (1) the newbuild transformation of Tbilisi does not imply a class remaking of its inner city, and (2) the inner city was never depopulated the way it became in many cities of the Global North. Both reasons reflect observations made elsewhere in the post-Communist world, suggesting that "gentrification" targets areas that were already well-reputed under socialism (Sýkora 2005) and that the inner cities have remained over-crowded due to the chronic housing shortages under socialism (Sýkora 1993, Gentile, Sjöberg 2010; Marcińczak, Sagan 2011). While the Central and Eastern European case study-based research reviewed in this article mostly concludes that this means that the phenomenon of gentrification is limited and geographically conscribed, the Georgian case calls for an alternative phraseology and interpretation - one that would capture a context that is largely ignored by the existing gentrification literature while certainly not without similarities to the situation present in other cities of the Global South. The main ingredients that have been identified in this article are the chemistry of urbanization and newbuild construction, the absence of a globally tailored habitat (cf. Davidson 2007) and, above all, tele-urbanization. On top of this, and contrary to axiomatic declarations by critical scholars on the topic (e.g., Davidson 2008; Wacquant 2008; Slater 2009; Davidson, Lees 2010), we have found no signs of displacement, displacement or social conflict induced by 
gentrification. As in the case of Edinburgh (Doucet 2009), we were surprised by the conspicuous absence of negative remarks. To the contrary, the residents of newbuilds - the time has come to drop the "gentrifier" label - and their neighbours appear to share similar concerns.

Finally, in what way can Tbilisi inform the broader gentrification debate? First and foremost, it contests a central aspect of the mythology of critical gentrification research: if gentrification is a global strategy, then it has not been effectively implemented in Tbilisi. Second, tele-urbanization as a concept may be helpful in addressing some of the contradictions concerning newbuild gentrification. To some extent, the Middle Eastern or Russian magnates who buy luxury apartments in London (Edwards 2011) share commonalities with the Georgian diaspora that invests in the Tbilisi real estate market. The price tags, motivations for buying, and overall governance framing may vary, but the result is similar nonetheless: an intense newbuild colonization of mainly historically prosperous areas by relatively affluent residents and phantom gentrifiers. Yet, despite these similarities, our study suggests that while "benign diagnosis" (Davidson 2010, p. 541) might not be the most fitting verdict on newbuild development in the post-Communist South, it does not deserve being dismissed a priori either - especially not on the grounds that typically sustain the arguments submitted by prominent critical scholars.

\section{References:}

ALEXANDER, C., BUCHLI, V., HUMPHREY, C. (2007): Urban life in post-Soviet Asia. UCL Press, London, $212 \mathrm{pp}$.

ÅSLUND, A. (2002): Building Capitalism. Cambridge University Press, Cambridge, 508 pp.

BADYINA, A., GOLUBCHIKOV, O. (2005): Gentrification in central Moscow - a market process or a deliberate policy? Money, power and people in housing regeneration in Ostozhenka. Geografiska Annaler B, 87, No. 1, pp. 113-129.

BATER, J. (1980): The Soviet City. Edward Arnold, London, 196 pp.

BEAUREGARD, R. (1986): The Chaos and Complexity of Gentrification. In: Smith, N., Williams, P. (eds.): Gentrification of the City. Allen \& Unwin, Boston, pp. 35-55.

BERNT, M. (2012): The "Double Movements" of Neighbourhood Change: Gentrification and Public Policy in Harlem and Prenzlauer Berg. Urban Studies, No. 49, pp. 3045-3062.

BERNT, M., HOLM, A. (2009): Is it, or is not? The conceptualisation of gentrification and displacement and its political implications in the case of Berlin-Prenzlauer Berg. City, 13, No. 2-3, pp. 312-324.

BODDY, M. (2007): Designer neighbourhoods: new-build residential development in nonmetropolitan UK citiesöthe case of Bristol. Environment and Planning A, 39, pp. 86-105.

BOREN, T., GENTILE, M. (2007): Metropolitan Processes In Post-Communist States: An Introduction. Geografiska Annaler: Series B, Human Geography, 89, No. 2, pp. 95-110.

BOUZAROVSKI, S., SALUKVADZE, J., GENTILE, M. (2011): A Socially Resilient Urban Transition? The Contested Landscapes of Apartment Building Extensions in Two Postcommunist Cities. Urban Studies, 48, No. 13, pp. 2689-2714.

BRIDGE, G. (2006): It's not just a question of taste: gentrification, the neighbourhood, and cultural capital. Environment and Planning A, 38, No. 10, pp. 1965-1978.

BUTLER, T. (2007): Re-urbanizing London Docklands: Gentrification, Suburbanization or New Urbanism? International Journal of Urban and Regional Research, 31, No. 4, pp. 759-781.

BUTLER, T., LEES, L. (2006): Super-gentrification in Barnsbury, London: globalization and gentrifying global elites at the neighbourhood level. Transactions of the Institute of British Geographers, 31, No. 4, pp. 467-487. 
BUTLER, T., ROBSON, G. (2001): Social Capital, Gentrification and Neighbourhood Change in London: A Comparison of Three South London Neighbourhoods. Urban Studies, 38, No. 12, pp. 2145-2162.

BUZAR, S., HALL, R., OGDEN, P.E. (2007): Beyond gentrification: the demographic reurbanisation of Bologna. Environment and Planning A, 39, No. 1, pp. 64-85.

CHELCEA, L. (2006): Marginal Groups in Central Places: Gentrification, Property Rights and Post-socialist Primitive Accumulation. In: Enyédi, G., Kovács, Z. (eds.): Social Changes and Social Sustainability in Historical Urban Centres: The Case of Central Europe Centre for Regional Studies of Hungarian Academy of Science, Pécs, pp. 127-145.

CHOI, N. (2014): Metro Manila through the gentrification lens: Disparities in urban planning and displacement risks. Urban Studies, pre-published online, DOI: 10.1177/0042098014543032.

DARIEVA, T. (2011): A Remarkable Gift in a Post-colonial City. The Past and Present of the Baku. Promenade. In: Darieva, T, Kaschuba, W., Krebs, M. (eds.): Urban Spaces After Socialism - Ethnographies of Public Places in Eurasian Citie. Campus Verlag, Frankfurt am Main, pp. 153-178.

DARIEVA, T., KASCHUBA, W., KREBS, M. (2011): Urban Spaces After Socialism - Ethnographies of Public Places in Eurasian Cities. Campus Verlag, Frankfurt am Main, 325 pp.

DAVIDSON, M. (2007): Gentrification as global habitat: a process of class formation or corporate creation? Transactions of the Institute of British Geographers, 32, No. 4, pp. 490-506.

DAVIDSON, M. (2008): Spoiled Mixture: Where Does State-led "Positive" Gentrification End? Urban Studies, 45, No. 12, pp. 2385-2405.

DAVIDSON, M. (2010): Love they neighbour? Social mixing in London's gentrification frontier. Environment and Planning A, 42, No. 3, pp. 524-544.

DAVIDSON, M., LEES, L. (2005): New-build gentrification and London's riverside renaissance. Environment and Planning A, 37, No. 7, pp. 1165-1190.

DAVIDSON, M., LEES, L. (2010): New-build gentrification: its histories, trajectories, and critical geographies. Population, Space and Place, 16, No. 5, pp. 395-411.

DINGSDALE, A. (1999): Budapest's built environment in transition. Geojournal, 49, pp. $63-78$.

DOUCET, B. (2009): Living through gentrification: subjective experiences of local, nongentrifying residents in Leith, Edinburgh. Journal of Housing and the Built Environment, 24, No. 3, pp. 299-315.

DOUCET, B., VAN KEMPEN, R., VAN WEESEP, J. (2011): 'We're a rich city with poor people': municipal strategies of new-build gentrification in Rotterdam and Glasgow. Environment and Planning A, 43, No. 6, pp. 1438-1454.

ECONOMIST (2010): A new look for old Tbilisi. 6 October.

EDWARDS, M. (2011): London for sale: towards the radical marketization of urban space. In: Gandy, M. (ed.): Urban constellations. Jovis, Berlin, pp. 54-57.

FLORIDA, R. (2002): The Rise of the Creative Class. Basic Books, New York, 404 pp.

FREEMAN, L. (2008): Comment on 'The Eviction of Critical Perspectives from Gentrification Research'. International Journal of Urban and Regional Research, 32, No. 1, pp. 186-191.

FREEMAN, L. (2009): Neighbourhood Diversity, Metropolitan Segregation and Gentrification: What Are the Links in the US? Urban Studies, 46, No. 10, pp. 2079-2101.

FREEMAN, L., BRACONI, F. (2004): Gentrification and displacement: New York City in the 1990s. American Planning Association, 70, No. 1, pp. 39-52.

FRENCH, A. (1995): Plans, pragmatism and people. UCL Press, London, $256 \mathrm{pp}$.

GARCIA-ZAMOR, J. (2014): Strategies for Urban Development in Leipzig, Germany. Springer, New York, $128 \mathrm{pp}$.

GENTILE, M., SJÖBERG, Ö. (2010): Spaces of Priority: The Geography of Soviet Housing Construction in Daugavpils, Latvia. Annals of the Association of American Geographers, 100, No. 1, pp. 112-136.

GLASS, R. (1964): Introduction: Aspects of Change. In: Centre for Urban Studies (ed.): London: Aspects of Change. McKibbon and Kee, London, pp. xiii-xlii.

GOLUBCHIKOV, O., BADYINA, A., MAKHROVA, A. (2014): The hybrid spatialities of transition: capitalism, legacy and uneven urban economic restructuring. Urban Studies, 51 No. 4, pp. 617-633. 
GRUBBAUER, M. (2012): Toward a more comprehensive notion of urban change: linking post-socialist urbanism and urban theory. In: Grubbauer, M., Kusiak, J. (eds.), Chasing Warsaw: Socio-Material Dynamics of Urban Change since 1990. Campus verlag, Frankfurt am Main, pp. 35-60.

HAASE, A., GROSSMANN, K., STEINFÜHRER, A. (2012): Transitory urbanites: New actors of residential change in Polish and Czech inner cities. Cities, 29, No. 5, pp. 318-326.

HACKWORTH, J., SMITH, N. (2001): The changing state of gentrification. Tijdschrift voor economische en sociale geografie, 92 , No. 4, pp. 464-477.

HAMNETT, C. (1991): The Blind Men and the Elephant: The Explanation of Gentrification. Transactions of the Institute of British Geographers, 16, No. 2, pp. 173-189.

HAMNETT, C. (2009): The new Mikado? Tom Slater, gentrification and displacement. City, 13 , No. 4, pp. 476-482.

HEGEDÜS, J., TOSICS, I. (1991): Gentrification in Eastern Europe: The case of Budapest. In: van Weesep, J., Musterd, S. (eds.): Urban Housing for the Better-Off: Gentrification in Europe. Stedelijke Netwerken, Utrecht, pp. 124-136.

HIRT, S. (2007): Suburbanizing Sofia: characteristics of post-socialist peri-urban change. Urban Geography, 28, No. 8, pp. 755-780.

HOLM, A., MARCINCZAK, S., OGRODOWCZYK, A. (2015): New-build gentrification in the post-socialist city: Łódź and Leipzig two decades after socialism. Geografie, 120, No. 2, pp. 164-187.

JONES LANG LASALLE, INSTITUTE OF POLLING AND MARKETING. (2012): Georgian Real Estate Market Overview 2012: Residential Market Report. JLL \& IPM, Tbilisi.

KABACHNIK, P., MITCHNECK, B., MAYOROVA, O. V., REGULSKA, J. (2014): The Multiple Geographies of Internal Displacement: The Case of Georgia. Refugee Survey Quarterly, 33, No. 4, pp. 1-30.

KABISCH, N., HAASE, D., HAASE, A. (2010): Evolving Reurbanisation? Spatio-temporal Dynamics as Exemplified by the East German City of Leipzig. Urban Studies, 47, No. 5, pp. 967-990.

KOCH, N. (2015): The violence of spectacle: Statist schemes to green the desert and constructing Astana and Ashgabat as urban oases. Social and Cultural Geography. Pre-published online, DOI: 10.1080/14649365.2014.1001431.

KOVÁCS, Z. (1998): Ghettoization or gentrification? Post-socialist scenarios for Budapest. Netherlands journal of housing and the built environment, 13, No. 1, pp. 63-81.

KOVÁCS, Z., WIESSNER, R., ZISCHNER, R. (2013): Urban Renewal in the Inner City of Budapest: Gentrification from a Post-socialist Perspective. Urban Studies, 50, No. 1, pp. 22-38.

KOVÁCS, Z., WIESSNER, R., ZISCHNER, R. (2015): Beyond gentrification: Diversified upgrading in the inner-city of Budapest. Geografie, 120, No. 2, pp. 250-273.

LEES, L. (2012): The geography of gentrification: Thinking through comparative urbanism. Progress in Human Geography, 36, No. 2, pp. 155-171.

LEMANSKI, C. (2014): Hybrid gentrification in South Africa: Theorising across southern and northern cities. Urban Studies, 51, No. 14, pp. 2943-2960.

MANNING, P. (2009): The Hotel/Refugee Camp Iveria: Symptom, Monster, Fetish, Home. In: van Assche, K., Salukvadze, J., Shavishvili, N. (eds.): Urban Culture and Urban Planning in Tbilisi: Where West and East Meet. Edwin Mellen Press, Lewiston, pp. 319-349.

MARCIŃCZAK, S., GENTILE, M., RUFAT, S., CHELCEA, L. (2014): Urban Geographies of Hesitant Transition: Tracing Socioeconomic Segregation in Post-Ceauşescu Bucharest. International Journal of Urban and Regional Research, 38, No. 4, pp. 1399-1417.

MARCIŃCZAK, S., GENTILE, M., STEPNIAK, M. (2013): Paradoxes of (Post)Socialist Segregation: Metropolitan Sociospatial Divisions Under Socialism and After In Poland. Urban Geography, 34, No. 3, pp. 327-352.

MARCIŃCZAK, S., MUSTERD, S., VAN HAM, M., TAMMARU, T. (2015): Inequality and rising levels of socio-economic segregation: lessons from a pan-European comparative study. In: Tammaru, T., van Ham, M., Marcińczak, S., Musterd, S. (eds.): Socio-Economic Segregation in European Capital Cities - East Meets West. Routledge, London, in press. 
MARCIŃCZAK, S., SAGAN, I. (2011): The Socio-spatial Restructuring of Łódź, Poland. Urban Studies, 48, No. 9, pp. 1789-1809.

MURZYN, M. (2006): "Winners" and "Losers" in the Game: the Social Dimension of Urban Regeneration in the Kazimierz quarter in Krakow. In: Enyédi, G., Kovács, Z. (eds.): Social Changes and Social Sustainability in Historical Urban Centres: The Case of Central Europe Centre for Regional Studies of Hungarian Academy of Science, Pécspp, pp. 81-106.

MURZYN, M. (2008): Heritage Transformation in Central and Eastern Europe. In: Graham, B., Howard, P. (eds.): The Ashgate Research Companion to Heritage and Identity. Ashgate, Aldershotpp, pp. 315-346.

NAGY, E., TIMÁR, J. (2012): Urban restructuring in the grip of capital and politics: Gentrification in East-Central Europe. In: Csapó, T., Balogh, A. (eds.): Development of the Settlement Network in the Central European Countries: Past, Present and Future. Springer Verlag, Berlin, Heidelberg, pp. 121-135.

O'HARA, S., IVLEVS, A., GENTILE, M. (2009): The Impact of Global Economic Crisis on Remittances in the Commonwealth of Independent States. Eurasian Geography and Economics, 50, No. 4, pp. 447-463.

OUŘEDNÍČEK, M. (2007): Differential suburban development in the Prague urban region. Geografiska Annaler B, 89, No. 2, pp. 111-126.

PHILIPS, M. (1993): Rural gentrification and the processes of class colonisation. Journal of Rural Studies, 9, No. 2, pp. 123-140.

PHILIPS, M. (2004): Other geographies of gentrification. Progress in Human Geography, 28, No. 1, pp. 5-30.

RÉRAT, P., SÖDERSTRÖM, O., PIGUET, E. (2010): New forms of gentrification: issues and debates. Population, Space and Place, 16, No. 5, pp. 335-343.

ROBINSON, J. (2002): Global and world cities: a view from off the map. International Journal of Urban and Regional Research, 26, No. 3, pp. 513-554.

ROBINSON, J. (2006): Ordinary Cities: Between Modernity and Development. Routledge, Abingdon, $224 \mathrm{pp}$.

ROBINSON, J. (2011): Cities in a World of Cities: The Comparative Gesture. International Journal of Urban and Regional Research, 35, No. 1, pp. 1-23.

ROSE, D. (2010): Local state policy and "new-build gentrification" in Montréal: the role of the "population factor" in a fragmented governance context. Population, Space and Place, 16, No. 5, pp. 413-428.

SAGAN, I., GRABKOWSKA, M. (2013): Negotiating Participatory Regeneration in the Postsocialist Inner City. In: Leary, M.E., Mccarthy, J. (eds.): The Routledge Companion to Urban Regeneration. Blackwell, London, New York, pp. 433-442.

SALUKVADZE, J., SICHINAVA, D., GOGISHVILI, D. (2013): Socio-economic and Spatial Factors of Alienation and Segregation of Internally Displaced Persons in the Cities of Georgia. In: Marszał, T., Pielesiak, I. (eds): Spatial Inequality and Cohesion, Studia Regionalia, 38, pp. 45-60.

SIMON, D. (2011): Situating Slums. City, 15, No. 6, pp. 674-685.

SJÖBERG, Ö. (2014): Cases onto themselves? Theory and research on ex-socialist urban environments. Geografie, 119, No. 4, pp. 299-319.

SLATER, T. (2006): The Eviction of Critical Perspectives from Gentrification Research. International Journal of Urban and Regional Research, 30, No. 4, pp. 737-757.

SLATER, T. (2009): Missing Marcuse: On gentrification and displacement'. City, 13, No. 2-3, pp. 293-311.

SLATER, T. (2010): Still missing Marcuse: Hamnett's foggy analysis in London town. City, 14, No. 1-2, pp. 170-179.

SMITH, N. (1979): Toward a Theory of Gentrification A Back to the City Movement by Capital, not People. Journal of the American Planning Association, 45, No. 4, pp. 538-548.

SMITH, N. (2002): New Globalism, New Urbanism: Gentrification as Global Urban Strategy. Antipode, 34, No. 3, pp. 427-450.

STABROWSKI, F. (2014): New-Build Gentrification and the Everyday Displacement of Polish Immigrant Tenants in Greenpoint, Brooklyn. Antipode, 46, No. 3, pp. 794-815. 
STEINFÜHRER, A., HAASE, A. (2007): Demographic changes as a future challenge for cities in East Central Europe . Geografiska Annaler: Series B, Human Geography, 89, No. 2, pp. 183-195.

SÝKORA, L. (1993): City in Transition: The Role of Rent Gaps in Prague's Revitalization. Tijdschrift voor economische en sociale geografie, 84, No. 4, pp. 281-293.

SÝKORA, L. (1999): Changes in the internal structure of postcommunist Prague. Geojournal, 49, No. 1 , pp. $79-89$.

SÝKORA, L. (2005): Gentrification in post-communist cities. In: Atkinson, R., Bridge, G. (eds.): Gentrification in Global Context: The New Urban Colonialism. Routledge, London, pp. 90-105.

SÝKORA, L., BOUZAROVSKI, S. (2012): Multiple Transformations: Conceptualising the Post-communist Urban Transition. Urban Studies, 49, No. 1, pp. 43-60.

SZELÉNYI, I. (1996): Cities under socialism - and after. In: Andrusz, G., Harloe, M., Szelényi, I. (eds.): Cities after Socialism: Urban and Regional Change and Conflict in Post-Socialist Societies, Blackwell, Oxford, pp. 286-317.

SZIRMAI, V. (2006): Socially Sustainable Urban Development in the Historic Urban Centres of East Central Europe. In: Enyédi, G., Kovács, Z. (eds.): Social Changes and Social Sustainability in Historical Urban Centres: The Case of Central Europe. Centre for Regional Studies of Hungarian Academy of Science, Pécs, pp. 20-38.

TAMMARU, T. (2005): Suburbanisation, employment change, and commuting in the Tallinn metropolitan area. Environment and Planning A, 37, No. 9, pp. 1669-1687.

TEMELOVÁ, J. (2007): Flagship developments and the physical upgrading of the postsocialist inner city: the Golden Angel project in Prague. Geografiska Annaler: Series B, Human Geography, 89, No. 2, pp. 169-181.

TEMELOVÁ, J., DVOŔÁKOVÁ, N. (2012): Residential satisfaction of elderly in the city centre: The case of revitalizing neighbourhoods in Prague. Cities, 29, No. 5, pp. 310-317.

VALIYEV, A. (2013): Baku. Cities, 31, No. 4, pp. 625-640.

VAN ASSCHE, K., SALUKVADZE, J. (2012): Tbilisi reinvented: planning, development and the unfinished project of democracy in Georgia. Planning Perspectives, 27, No. 1, pp. 1-24.

VAN KEMPEN, R., MURIE, A. (2009): The new divided city: changing patterns in European cities. Tijdschrift voor economische en sociale geografie, 100, No. 4, pp. 377-398.

VENDINA, O. (1997): Transformation Processes in Moscow and Intra-Urban Stratification of Population. Geojournal, 42, No. 4, pp. 349-363.

WACQUANT, L. (2004): Critical Thought as Solvent of Doxa. Constellations, 11, No. 1, pp. 97-101.

WACQUANT, L. (2008): Relocating gentrification: the working class, science and the state in recent urban research. International Journal of Urban and Regional Research 32, No. 1, pp. 198-205.

\section{Shrnutí}

\section{GENTRIFIKACE FORMOU NOVÉ VÝSTAVBY, TELE-URBANIZACE A RŮST MĚST: POSTAVENÍ MĚST JIŽNÍCH POST-KOMUNISTICKÝCH STÁTŮ V DEBATĚ O GENTRIFIKACI}

Loretta Lees ve svém nedávno publikovaném článku (2012) vyzývá k intenzivnějšímu dialogu mezi výzkumem gentrifikace a studiem komparativního urbanismu. Zejména upozorňuje na to, že gentrifikace v zemích „globálního jihu“ by neměla být chápána pouze jako reflexe prostorového vývoje známého z předpokládaného centra. Přestože post-komunistická města bývají v tomto ohledu přehlížena i nejvíce globálně orientovanými výzkumníky, nedávný článek v Geografii upozorňuje na jejich potenciál pro tvorbu vhodných teorií (Sjöberg 2014). Naše rešerše literatury $k$ tématu gentrifikace $v$ post-komunistických městech identifikovala tři základní charakteristiky jejích výstupů: (a) tvrzení, že se jedná o fenomén smíšené povahy a převážně malého rozsahu, (b) porovnávání nálezů s teoretickým rámcem vyvinutým na „Západě“, (c) nevšímavost vưči většině post-komunistického světa, včetně vlastních periferií. 
S ohledem na tento stav, článek přispívá do debaty výzkumem nové domovní výstavby ve městě Tbilisi v Gruzii z pohledu gentrifikace formou nové výstavby.

Tbilisi patří zároveň mezi post-komunistická města i metropole Globálního jihu. Jinými slovy se tak jedná o město „post-komunistického jihu“. Naše výzkumné otázky jsou položeny formou „kdo stavi“, „kdo kupuje“ a „co se děje s rezidenčními komunitami“? Na tyto otázky odpovídáme analýzou výstupů získaných z rozhovorů s developery, obchodníky s realitami, obyvateli/majiteli novostaveb a usedlíky, kteří se osobně na gentrifikaci přímo nepodílejí. Náš cíl byl v této fázi primárně explorativní.

Interpretovat získané výstupy skrze prizma gentrifikace formou nové výstavby se ukazuje jako neúčelné, přestože by to bylo z teoretického pohledu lákavé a i povrchní pozorování zkoumaného problému by k tomu mohlo svádět. Namísto toho př́klad Tbilisi ilustruje potřebu správného zhodnocení zkoumaného kontextu: spíše než revanšistický návrat vnitřního města do rukou střední třídy, reflektuje nová domovní výstavba v Tbilisi spíše demografický vývoj a slouží jako úložiště kapitálu přicházejícího $\mathrm{z}$ diaspory. Tento stav vede $\mathrm{k}$ velké míre aktivní nové výstavby i přes současnou nízkou úroveň zaplněnosti existujících obytných budov. Proces můžeme chápat jako určitou formu dálkově ovládaného městského růstu neboli „tele-urbanizace“.

Teorie gentrifikace, at’ již kritická či nikoliv, je založená na desetiletí akademického zájmu o vývoj vnitřních měst v zemích „globálního severu“. Toto porozumění ale čelí zásadním výzvám ve vztahu $\mathrm{k}$ neúplné urbanizaci a rapidním společenských a prostorovým změnám existujícím v post-komunistickém kontextu. V Tbilisi, kde se setkávají vlivy a dopady urbanizace, investic přicházejících z diaspory a celkový nedostatek obytných prostorů vzniklý v období sovětské nadvlády, tak vzniknul dynamický a obtížně popsatelný vzorec městské proměny, a to zejména v jeho prestižních čtvrtích. Vizuálně tyto procesy připomínají kolonizaci novostavbami tak, jak je spojena s neoliberální gentrifikací třetí vlny ve světě (Hackworth, Smith 2001; Smith 2002), čímž by se Tbilisi mohlo zařadit do stále rostoucího seznamu měst, které tato nezastavitelná síla zasáhla. Taková interpretace by ale zakryla mnohem složitější realitu, ve které se městský prostor vyvíjí na pomezí sovětského historického dědictví a tržní transformace na pozadí městského plánování v duchu politické nestability a ozbrojeného konfliktu. I v takto neklidném prostředí je pochopitelně také místo pro klasickou gentrifikaci a gentrifikaci formou nové výstavby, ovšem stejně jako v případě mnoha středoevropských či východoevropských měst nelze tyto fenomény považovat za významné - či dokonce rozhodující - aspekty stavebního zhuštování v Tbilisi.

Gruzínský případ si tedy žádá nové názvosloví a interpretační rámec, jaký by se hodil pro kontext doposud opomíjený existující literaturou o gentrifikaci a který vykazuje podobnosti se situací panující v dalších městech „globálního jihu“.

Hlavními prvky v tomto kontextu jsou tak podle toho článku urbanizace a výstavba novostaveb, absence zřejmých globálních trendů a „tele-urbanizace“. V přímém rozporu s předpoklady kriticky orientovaných autorů (např. Davidson 2008; Wacquant 2008; Slater 2009; Davidson, Lees 2010) jsme nenalezli žádné známky populačních přesunů či sociálních konfliktů spojených s gentrifikací.

Jakým způsobem tedy může případová studie Tbilisi obohatit diskuzi o gentrifikaci? Zejména představuje výzvu pro jeden z centrálních aspektů kritického výzkumu gentrifikace: pokud je gentrifikace skutečně globálně aplikovanou strategií, tak v Tbilisi tedy rozhodně k jejímu efektivnímu využití nedošlo. Za druhé, koncept „tele-urbanizace“ může být využit $\mathrm{k}$ řešení některých neshod s ohledem na gentrifikaci formou nové výstavby. Magnáti z Ruska nebo Blízkého východu, kteří skupují luxusní byty v Londýně (Edwards 2011) sdílejí některé podobnosti s gruzínskou diasporou investující do realit ve vnitřním Tbilisi. Ceny, motivace a celkový př́stup se mohou lišit, ale dopady jejich chování se v mnohém shodují: intenzivní kolonizace prosperujících oblastí novou výstavbou patřící movitějším obyvatelům nebo absentujícím aktérům gentrifikace. I přes tyto podobnosti ale naše studie tvrdí, že ačkoliv nemusí být „benigní diagnóza“ (Davidson 2010, p. 541) nejsprávnějším popisem vývoje novostaveb ve městech post-komunistického jihu, není ani důvod ji a priori odmítat, zejména na základě argumentů kritických autorů. 
Obr. 1 -Rozložení domů v Tbilisi podle období, ve kterém byly postaveny.

Obr. 2 -Objem prodaného obytného prostoru $\mathrm{v}$ Tbilisi $\mathrm{v}^{2}$ a počtu jednotek $\mathrm{v}$ období 2006-2012.

Obr. 3 -Ekletické řešení nově postavené budovy v centru Tbilisi.

Authors' affiliation: M. Gentile: University of Helsinki, Department of Geosciences and Geography; e-mail: michael.gentile@helsinki.fi. J. Salukvadze: Ivane Javakhishvili Tbilisi State University, Department of Human Geography, Tbilisi, Georgia. D. Gogishvili: Gran Sasso Science Institute, Italy, and Ivane Javakhishvili Tbilisi State University, Tbilisi, Georgia.

Initial submission, 2 July 2014; final acceptance 18 April 2015.

\section{Please cite this article as:}

GENTILE, M., SALUKVADZE, J., GOGISHVILI, D. (2015): Newbuild gentrification, tele-urbanization and urban growth: placing the cities of the post-Communist South in the gentrification debate. Geografie, 120, No. 2, pp. 134-163. 